\title{
Auerbakhite, $\mathrm{MnTl}_{2} \mathrm{As}_{2} \mathrm{~S}_{5}$, a new thallium sulfosalt from the Vorontsovskoe gold deposit, Northern Urals, Russia
}

\author{
Anatoly V. KASATKIN ${ }^{1 *}$, Jakub PLÁŠIL2 ${ }^{2}$ Emil MAKOVICKY ${ }^{3}$, Nikita V. CHUKANOV ${ }^{4}$, Radek \\ ŠKODA ${ }^{5}$, Atali A. AGAKHANOV', Sergey Y. STEPANOV ${ }^{6}$, Roman S. PALAMARCHUK ${ }^{7}$ \\ ${ }^{1}$ Fersman Mineralogical Museum of Russian Academy of Sciences, Leninsky Prospekt 18-2, 119071 Moscow, Russia; \\ anatoly.kasatkin@gmail.com \\ ${ }^{2}$ Institute of Physics, Academy of Sciences of the Czech Republic v.v.i, Na Slovance 1999/2, Prague 8, 182 21, Czech Republic \\ ${ }^{3}$ Department of Geoscience and Resource Management, University of Copenhagen, Østervoldgade 10, DK-1350, Copenhagen K, \\ Denmark \\ ${ }^{4}$ Institute of Problems of Chemical Physics, Russian Academy of Sciences, Chernogolovka, Moscow region, 142432 Russia \\ ${ }^{5}$ Department of Geological Sciences, Faculty of Science, Masaryk University, Kotlářská 2, 611 37, Brno, Czech Republic \\ ${ }^{6}$ Institute of Geology and Geochemistry, UB RAS, Akademika Vonsovskogo 15, Yekaterinburg, 620016 Russia \\ ${ }^{7}$ South Urals Federal Research Center of Mineralogy and Geoecology UB RAS, Institute of Mineralogy, Miass, Chelyabinsk oblast, \\ 456317 Russia \\ * Corresponding author
}

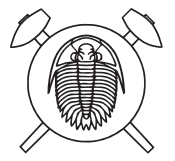

Auerbakhite (IMA 2020-047), $\mathrm{MnTl}_{2} \mathrm{As}_{2} \mathrm{~S}_{5}$, is a new sulfosalt from the Vorontsovskoe gold deposit, Sverdlovsk Oblast', Northern Urals, Russia. The new mineral occurs in limestone breccias composed of calcite, dolomite, baryte, clinochlore, fluorapatite and quartz, and cemented by major realgar, orpiment and pyrite. Other minerals directly associating with auerbakhite include alabandite, bernardite, christite, cinnabar, coloradoite, dalnegroite, gillulyite, gold, hutchinsonite, imhofite, lorándite, metacinnabar, philrothite, rebulite, routhierite, sphalerite, and vrbaite. Auerbakhite forms rare and very small short-prismatic crystals and irregular grains which do not exceed $15 \times 5 \mu \mathrm{m}$. It is transparent, has a bright red color and adamantine luster. Auerbakhite is brittle, with an uneven fracture. Cleavage is not observed. The calculated density is $5.245 \mathrm{~g} / \mathrm{cm}^{3}$. In reflected light, auerbakhite is light gray, weakly bireflectant. In crossed polars, it is distinctly anisotropic, in light gray and brown tones, with abundant bright red internal reflections. The empirical formula of auerbakhite is $\mathrm{Mn}_{1.04} \mathrm{Tl}_{1.97} \mathrm{~Pb}_{0.02} \mathrm{As}_{1.95} \mathrm{~S}_{5.02}$ (based on 10 atoms $p f u$ ). Prominent features in the Raman spectrum include bands of $\mathrm{Mn}-\mathrm{S}$ and As-S stretching vibrations and numerous low-frequency bands related to mixed soft modes involving bending and Tl-S stretching vibrations. Auerbakhite is orthorhombic, space group Cmce, $a=15.3280(15)$ $\AA, b=7.662(7) \AA, c=16.6330(14) \AA, V=1953.40(18) \AA^{3}$ and $Z=8$. The crystal structure of auerbakhite was refined from the single-crystal X-ray diffraction data to $R=0.0723$ for 307 observed reflections with $I_{\text {obs }}>3 \sigma(I)$. Auerbakhite is isostructural to the synthetic phase $\mathrm{Tl}_{2} \mathrm{MnAs}_{2} \mathrm{~S}_{5}$. Its crystal structure consists of complex (001) layers based on a set of $\mathrm{MnS}_{4}$ columns parallel to [010] and are composed of edge-sharing slightly irregular $\mathrm{MnS}_{6}$ octahedra. The columns are connected via Tl1 and are framed by paired $\mathrm{AsS}_{3}$ pyramids with lone electron pairs oriented into interlayer space. Highly irregular $\mathrm{Tl}(2) \mathrm{S}_{6}$ coordination polyhedra are situated in interlayers and share ligands with the layers. The new mineral honors Russian mining engineer, manufacturer and mineralogist Alexander Andreevitch Auerbakh whose activities were closely related to Northern Urals.

Keywords: auerbakhite, new sulfosalt, thallium, crystal structure, Vorontsovskoe gold deposit, Northern Urals Received: 6 March 2021; accepted: 9 April 2021; handling editor: F. Laufek

The online version of this article (doi: 10.3190/jgeosci.321) contains supplementary electronic material.

\section{Introduction}

The Vorontsovskoe gold deposit at Northern Urals is unique in Russia and in the world concerning the diversity and originality of the $\mathrm{Tl}-\mathrm{Hg}-\mathrm{Mn}-\mathrm{As}-\mathrm{Sb}-\mathrm{S}$ mineralization. Its ores contain more than 70 rare sulfides, tellurides and sulfosalts, including 30 with thallium, 12 with mercury, and 9 with manganese as species-defining elements (Kasatkin et al. 2020b). Among them, eight mineral species were discovered by our team as entirely new for the science: vorontsovite, ferrovorontsovite (Kasatkin et al. 2018b), tsygankoite (Kasatkin et al. 2018a), gladkovskyite (Kasatkin et al. 2019), luboržákite (Kasatkin et al. 2020a), pokhodyashinite (Kasatkin et al. 2020c), gungerite (Kasatkin et al. 2021), and auerbakhite described herein.

Auerbakhite (pronouncing: a u a ba khit; Russian Cуrillic ауэрбахит) is named for Alexander Andreevitch Auerbakh (1844-1916), Russian mining engineer, manufacturer and mineralogist. At the end of the $19^{\text {th }}$ century, 
his activities were closely related to Northern Urals. In 1884 he founded the Tur'inskiy Mining School at the famous Tur'inskie Copper Mines. During 1881-1896 he managed the Bogoslovskiy mining district, developed and improved the region's copper smelting production. The Auerbakh intrusion and Auerbakh ore district comprising the Vorontsovskoe gold deposit are named after him. A.A. Auerbakh is the author of several mineralogical papers - see, e.g., Auerbakh (1869) - and was the first one in Russia who used microscopic techniques to study minerals. We find it symbolic of naming after him a mineral of a tiny size which has been discovered under the scanning electron microscope.

The new mineral and its name have been approved by the Commission on New Minerals, Nomenclature and Classification of the International Mineralogical Association (IMA 2020-047). The type specimen is deposited in the collections of the Fersman Mineralogical Museum of the Russian Academy of Sciences, Moscow, Russia with the registration number 5579/1.

\section{Occurrence}

Vorontsovskoe gold deposit is located in Krasnotur'inskiy district of Sverdlovsk Oblast' (Northern Urals), $0.5 \mathrm{~km}$ $\mathrm{W}$ of Vorontsovka settlement, $13 \mathrm{~km} \mathrm{~S}$ of the town of Krasnotur'insk and approximately $310 \mathrm{~km} \mathrm{~N}$ of Yekaterinburg. It was discovered in 1985 and since 1999, its exploitation has been performed by the mining company PLC "Polymetal" utilizing two open pits - Northern (240 m deep) and Southern (80 m deep). A detailed description of the Vorontsovskoe deposit, its genesis, geology and composition of main types of ores can be found elsewhere (Vikentyev et al. 2016; Kasatkin et al. 2019; Kasatkin et al. 2020a and references therein). The most recent summary of the history of the study of the

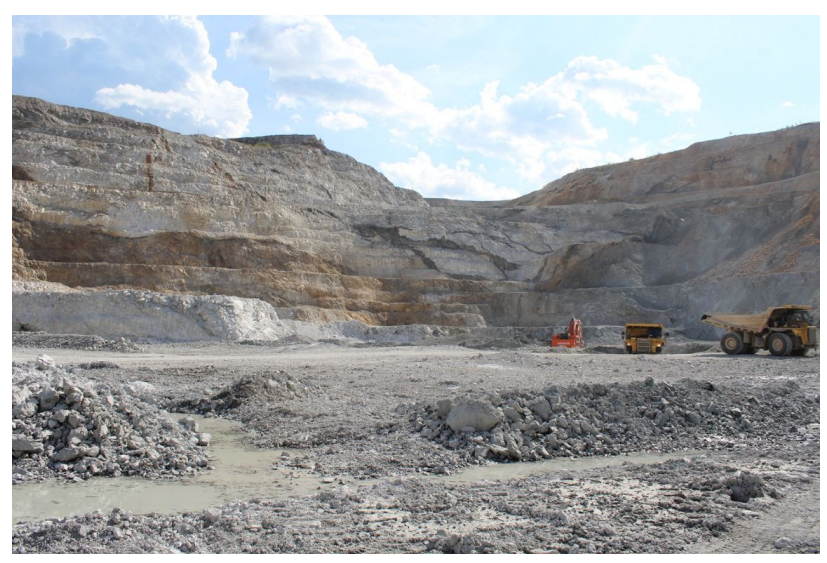

Fig. 1 Northern open pit of Vorontsovskoe deposit where samples containing auerbakhite were collected. August 2016. Photo by S. Yu. Stepanov. deposit, its geological background, detailed description of the main mineral assemblages were given by Kasatkin et al. (2020b). The last paper also provides an exhaustive list of 209 mineral species identified there.

Geologically, the Vorontsovskoe deposit lies on the eastern slope of the Northern Urals, in the eastern part of the Tagil volcanic zone, within the volcano-plutonic belt of submeridional strike. This belt was formed due to the collision of the Tagil island arc with the East Ural microcontinent. Auerbakh gabbro-diorite-granodiorite intrusion of the Middle Devonian age is located in the southern part of that volcano-plutonic belt. The Vorontsovsko-Peschanskaya ore-magmatic system is situated in the southwestern exocontact of the Auerbakh intrusion. Vorontsovskoe deposit is located in the southern part of the system, at some distance from the contact with the intrusive rocks of the Auerbakh intrusion. The volcanic-sedimentary beds, which enclose the Vorontsovskoe deposit, form a monocline that slopes gently to the west and plunges to the north. The base of this structure consists of limestones, often largely converted to marbles, with interlayers of tuffites and siltstones. This stratum is consistently overlain by volcanicsedimentary and volcanic rocks: tuff aleurolites, tuffites, diorite porphyrites and tuffs. The Northern open pit of the Vorontsovskoe deposit exposed a wedge-shaped body of volcanogenic-sedimentary rocks dominated by tuffs of intermediate composition and tuffaceous sandstones. Both limestones and volcanic-sedimentary rocks are subject to brecciation. Breccias consist of semi-rounded and angular limestone fragments up to $25 \mathrm{~cm}$ in size, cemented by clay-carbonate and volcanic-sedimentary material (Kasatkin et al. 2020b). Our systematic studies of the samples collected at the deposit in 2013-2020 show that the most extraordinary richness and variety of mineral species occur exactly in ore breccias developed over carbonate rocks. They contain various rare minerals (mainly sulfosalts) with species-defining $\mathrm{Tl}, \mathrm{Hg}, \mathrm{Pb}$ and Mn identified in the deposit, including eight new species mentioned above.

Specimens containing auerbakhite were collected in August 2016 at the lowest horizons of the Northern open pit of the deposit, $50 \mathrm{~m}$ from its western wall, directly at the bottom of the pit $\left(59^{\circ} 39^{\prime} 12^{\prime \prime} \mathrm{N}, 60^{\circ} 12^{\prime} 53^{\prime \prime} \mathrm{E}\right)$ (Fig. 1). Auerbakhite occurs in the same mineral assemblage as gladkovskyite (Kasatkin et al. 2019) and has been found in limestone breccias composed of Mn-rich carbonates (calcite and dolomite), baryte, clinochlore, fluorapatite and quartz, and cemented by major realgar, orpiment and pyrite. Other minerals directly associating with auerbakhite include alabandite, bernardite, christite, cinnabar, coloradoite, dalnegroite, gillulyite, gold, hutchinsonite, imhofite, lorándite, metacinnabar, philrothite, rebulite, routhierite, sphalerite, and vrbaite. 
Fig. 2 Two grains of auerbakhite (Arb) in calcite (very dark-grey) and quartz (black) in association with realgar (Rlg) and pyrite (Pyr). These grains were the biggest ever found and have been extracted for structural studies. Polished section. SEM (BSE) image.

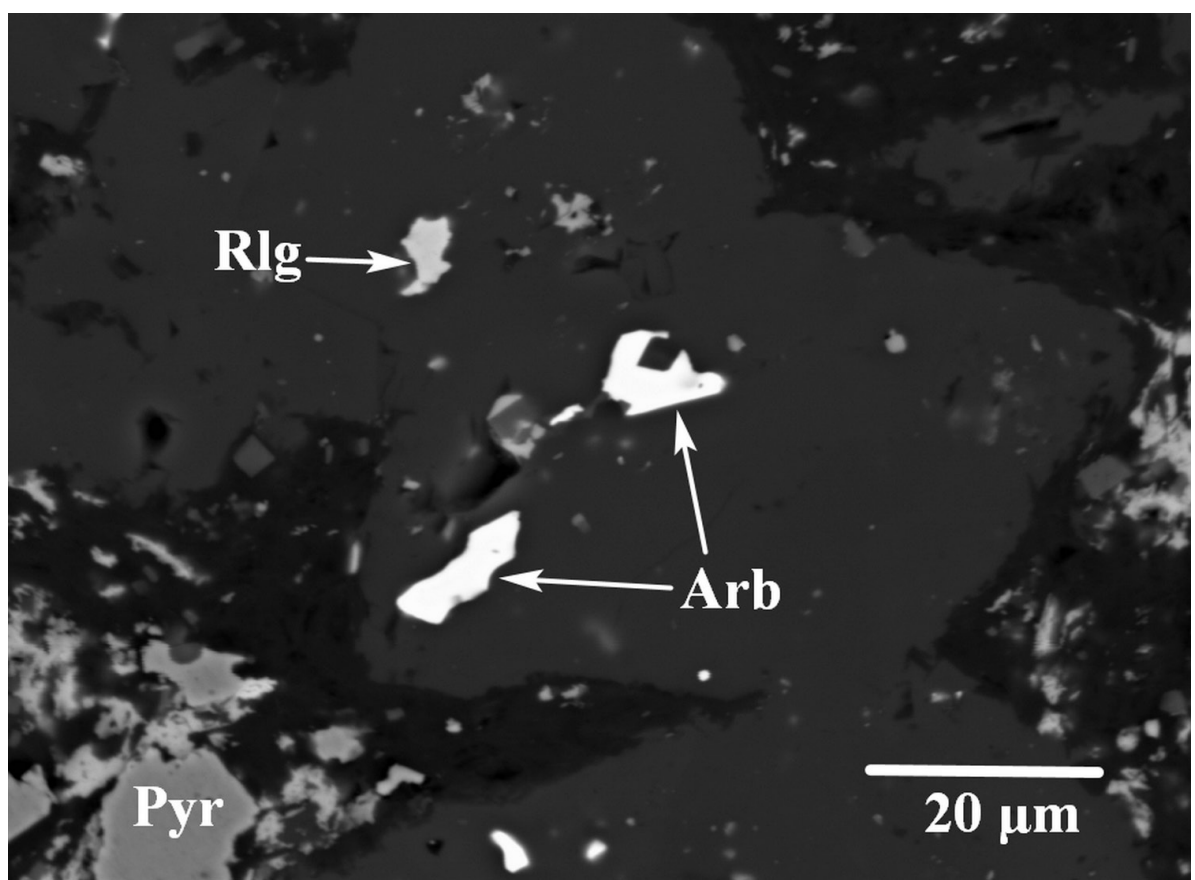

\section{Physical and optical properties}

Auerbakhite forms rare and very small short-prismatic crystals and irregular grains which do not exceed $15 \times 5$ $\mu \mathrm{m}$, and, as a rule, are even smaller (Fig. 2). Auerbakhite is transparent, has a bright red color and adamantine luster. It is brittle, with an uneven fracture. Cleavage is not observed. Its hardness and density could not be measured because of the extremely small size of the grains. The density calculated from the empirical formula $(Z=8)$ and the unit-cell volume determined from the single-crystal X-ray diffraction data is $5.245 \mathrm{~g} / \mathrm{cm}^{3}$. In reflected light, auerbakhite is light gray, weakly bireflectant. In crossed polars, it is distinctly anisotropic, in light gray and brown tones. Internal reflections are abundant and have a bright red color. They are distinct in air and strong in immersion. In transmitted light, auerbakhite is moderately pleochroic, from orange-red to dark red. Reflectance values for wavelengths recommended by the Commission on Ore Mineralogy of the IMA are $\left(R_{\min } / R_{\max }, \%\right): 25.2 / 27.1$ $(470 \mathrm{~nm}), 24.0 / 25.2(546 \mathrm{~nm})$, $23.7 / 24.7(589 \mathrm{~nm}), 23.0 / 24.0$ $(650 \mathrm{~nm})$. The complete set of reflectance measurements performed in the air relative to a WTiC standard employing a Universal Microspectrophotometer UMSP 50 (Opton-Zeiss, Germany) is given in Tab. 1 and plotted in Fig. 3.
Tab. 1 Reflectance values of auerbakhite (measured in air)

\begin{tabular}{llllll}
\hline $\mathrm{R}_{\max }$ & $\mathrm{R}_{\min }$ & $\lambda(\mathrm{nm})$ & $\mathrm{R}_{\max }$ & $\mathrm{R}_{\min }$ & $\lambda(\mathrm{nm})$ \\
\hline 34.8 & 26.8 & 400 & 24.9 & 23.9 & 560 \\
33.0 & 26.3 & 420 & 24.8 & 23.8 & 580 \\
31.3 & 25.9 & 440 & 24.7 & 23.7 & $589(\mathrm{COM})$ \\
28.5 & 25.5 & 460 & 24.5 & 23.5 & 600 \\
27.1 & 25.2 & $470(\mathrm{COM})$ & 24.3 & 23.4 & 620 \\
26.5 & 24.8 & 480 & 24.1 & 23.2 & 640 \\
25.9 & 24.5 & 500 & 24.0 & 23.0 & $650(\mathrm{COM})$ \\
25.7 & 24.3 & 520 & 23.9 & 22.8 & 660 \\
25.5 & 24.1 & 540 & 23.8 & 22.7 & 680 \\
25.2 & 24.0 & $546(\mathrm{COM})$ & 23.7 & 22.6 & 700 \\
\hline
\end{tabular}




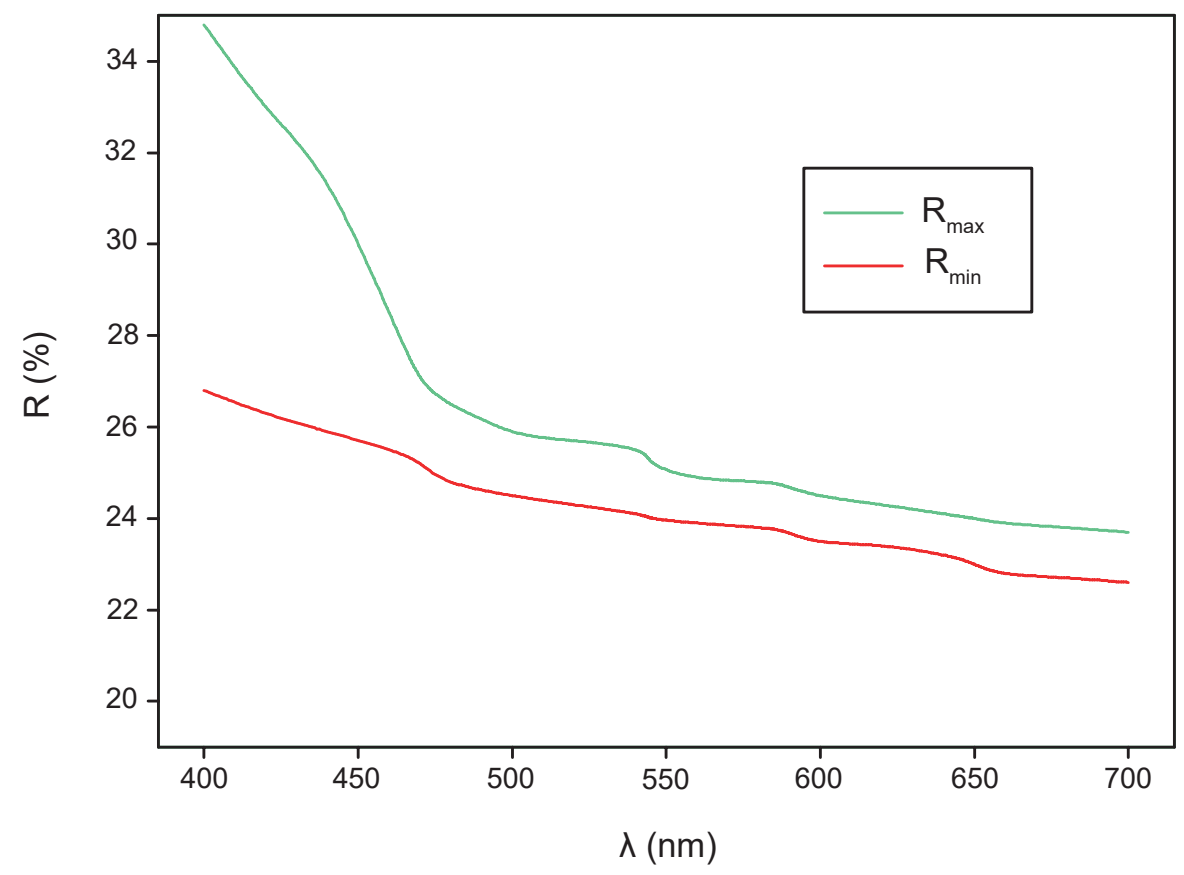

Fig. 3 Reflectivity curves for auerbakhite in air. spectral resolution was $\sim 2 \mathrm{~cm}^{-1}$. Band fitting was done after appropriate background correction, assuming combined Lorentzian-Gaussian band shapes using the Voigt function (PeakFit; Jandel Scientific Software).

The assignment of the Raman bands of auerbakhite was made by analogy with gladkovskyite (Kasatkin et al. 2019). In both minerals, the most high-force-strength bonds are $\mathrm{Mn}-\mathrm{S}$. Bands of $M-\mathrm{S}$ stretching vibrations in the Raman spectra of pyrite-type compounds $M \mathrm{~S}_{2}$ $(M=\mathrm{Mn}, \mathrm{Co}, \mathrm{Ni}, \mathrm{Cu}, \mathrm{Zn})$ with systems of vertex-sharing $M \mathrm{~S}_{6}$ octahedra are observed in the range of 380-500 $\mathrm{cm}^{-1}$ (Anastassakis and Perry 1976). For gladkovskyite

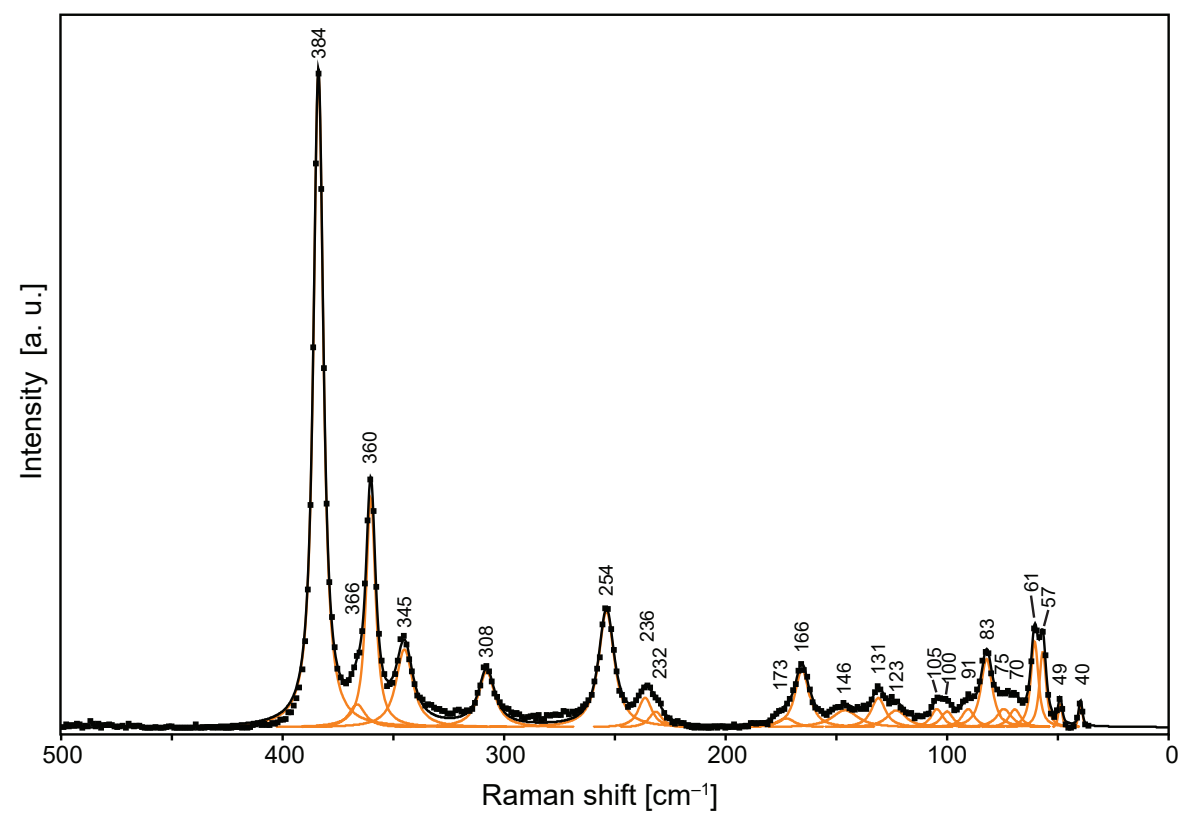

and auerbakhite, which contain $1 \mathrm{D}$ systems of $\mathrm{MnS}_{6}$ octahedra, somewhat lower frequencies should be expected. This conclusion is in agreement with the positions of the strong high-frequency bands observed in the Raman spectra of both minerals in the range of 350-400 $\mathrm{cm}^{-1}$.

Raman bands of As-S stretching vibrations in the Raman spectra of orpiment $\mathrm{As}_{2} \mathrm{~S}_{3}$ and realgar $\mathrm{AsS}$ are observed in the range of $290-360 \mathrm{~cm}^{-1}$ (Forneris 1969; Minceva-Sukarova et al. 2003). In these minerals, the As-S distances are in the range of 2.21-2.31 (Morimoto 1954; Mullen and Nowacki 1972). The largest bonding distances correspond to the lowest frequencies of As-S stretching vibrations. In auerbakhite, the shortest As-S distances of the $\mathrm{AsS}_{4}$ and $\mathrm{AsS}_{3}$ pyramids are in the range of 2.23-2.31 $\AA$. Consequently, the bands in the range of 300-350 $\mathrm{cm}^{-1}$ in the Raman spectrum of auerbakhite are assigned to As-S stretching vibrations.

The assignment of Raman bands with wavenumbers below $260 \mathrm{~cm}^{-1}$ is ambiguous. Presumably, these bands correspond to mixed soft modes involving

Fig. 4 Raman spectrum of auerbakhite (excited by $633 \mathrm{~nm}$ laser). The measured spectrum is represented by the dots. The black curve matching to the dots results from spectral fit as a sum of individual Voigt peaks (orange). 
bending vibrations, as well as Tl-S stretching vibrations.

\section{Chemical composition}

Preliminary semi-quantitative chemical analyses using a scanning electron microscope CamScan 4D (Fersman museum, Moscow) equipped with INCA Energy microanalyzer (EDS mode, $20 \mathrm{kV}, 5 \mathrm{nA}$ and beam diameter 1 $\mu \mathrm{m}$ ) showed the presence of essential Mn, Tl, As, S, and traces of $\mathrm{Pb}$ in auerbakhite. Contents of other elements with atomic numbers higher than that of carbon were below detection limits.

Quantitative chemical analyses were conducted in the wavelength-dispersive (WDS) mode, using a Cameca SX100 electron microprobe (Masaryk University, Brno) operated at $25 \mathrm{kV}$ and $20 \mathrm{nA}$ with the beam size of 1 $\mu \mathrm{m}$. Peak counting times were $20 \mathrm{~s}$ for all elements, with one-half of the peak time for each background. The following standards, X-ray lines, and crystals (in parentheses) were used: Mn: Mn metal, $K_{\alpha}$ (LIF); $\mathrm{Tl}: \mathrm{Tl}(\mathrm{Br}, \mathrm{I})$, $M_{\alpha}$ (PET); Pb: PbSe, $M_{\alpha}$ (PET); As: pararammelsbergite, $L_{\beta}$ (TAP); S: chalcopyrite, $K_{\alpha}$ (PET). Raw X-ray intensities were corrected for matrix effects with a $\phi(\rho z)$ algorithm of X-PHI routine (Merlet 1994). Analytical data are given in Tab. 2 (mean of 7 analyses). No other elements with atomic numbers higher than 8 were detected.

The empirical formula of auerbakhite (based on the sum of all atoms $=10 \mathrm{pfu}$ ) is $\mathrm{Mn}_{1.04} \mathrm{Tl}_{1.97} \mathrm{~Pb}_{0.02} \mathrm{As}_{1.95} \mathrm{~S}_{5.02}$. The ideal chemical formula is $\mathrm{MnTl}_{2} \mathrm{As}_{2} \mathrm{~S}_{5}$, which requires Mn 7.10, Tl 52.81, As 19.37, S 20.72 , total 100 wt. $\%$.

\section{X-ray crystallography}

Single-crystal X-ray diffraction data were collected on an extremely small, plate-like singlecrystal fragment of auerbakhite, of the approximate dimensions $10 \times 8 \times 5 \mu \mathrm{m}$, embedded in a calcite chip and extracted from the polished section used for EPMA investigations. It was
Tab. 3 Summary of data collection conditions and refinement parameters for auerbakhite

\begin{tabular}{ll}
\hline Chemical formula sum & $\mathrm{Tl}_{2} \mathrm{MnAs}_{2} \mathrm{~S}_{5}$ \\
Crystal system & Orthorhombic \\
Space group & Cmce \\
Unit-cell parameters: $a, b, c[\AA]$ & $15.3280(15), 7.662(7), 16.6330(14)$ \\
Unit-cell volume $\left[\AA^{3}\right]$ & $1953.40(18)$ \\
$Z$ & 8 \\
Calculated density $\left[\mathrm{g} / \mathrm{cm}^{3}\right]$ & 5.263 (for the formula from the structure) \\
Crystal size [mm] & $0.010 \times 0.008 \times 0.005$ \\
Diffractometer & Rigaku SuperNova with Atlas S2 CCD \\
Temperature $[\mathrm{K}]$ & 293 \\
Radiation, wavelength $[\AA]$ & $\mathrm{Mo} K_{\alpha}, 0.71073(50 \mathrm{kV}, 30 \mathrm{~mA})$ \\
$\theta$ range for data collection $\left[{ }^{\circ}\right]$ & $3.21-28.65$ \\
Limiting Miller indices & $h=-19 \rightarrow 13, k=-9 \rightarrow 9, l=-21 \rightarrow 17$ \\
Axis, frame width $\left({ }^{\circ}\right)$, time per frame $(\mathrm{s})$ & $\omega, 1.0,700$ \\
Total reflections collected & 5577 \\
Unique reflections & 1121 \\
Unique observed reflections, criterion & $307,[I>3 \sigma(I)]$ \\
Absorption coefficient $\left[\mathrm{mm}{ }^{-1}\right]$, type & $41.90 ;$ multi-scan \\
$T_{\text {min }} / T_{\text {max }}$ & $0.547 / 1$ \\
Data completeness to $\theta_{\text {max }}(\%), R_{\text {int }}$ & $85.00,0.301$ \\
Structure refinement & Full-matrix least-squares on $F^{2}$ \\
No. of param., restraints, constraints & $50,0,0$ \\
$R, w R$ (obs) & $0.0723,0.1535$ \\
$R, w R$ (all) & $0.2931,0.2470$ \\
GOF obs/all & $1.43,1.18$ \\
Weighting scheme, weights & $\sigma, w=1 /\left(\sigma^{2}(I)+0.0009 I^{2}\right)$ \\
Largest diffraction peak and hole $\left(\mathrm{e}-/ \AA^{3}\right)$ & $29.05(0.1 \AA$ to $\mathrm{Tl1}),-12.34$ \\
\hline &
\end{tabular}

mounted on glass fiber and examined with a Rigaku SuperNova single-crystal diffractometer equipped with the Atlas S2 CCD detector and a microfocus $\mathrm{Mo} K_{\alpha}$ source (Institute of Physics, Prague). Data reduction was performed using CrysAlisPro Version 1.171.39.46 (Rigaku 2019). The data were corrected for Lorentz factor, polarization effect and absorption (multi-scan, ABSPACK scaling algorithm; Rigaku 2019).

The crystal structure of auerbakhite was refined based on single-crystal X-ray data starting from the structure model of the synthetic $\mathrm{MnTl}_{2} \mathrm{As}_{2} \mathrm{~S}_{5}$ (Gostojić et al. 1982) using the software Jana2006 (Petríčck et al. 2014). The structure refinement smoothly converged to $R=0.0723$ for 307 reflections with $I>3 \sigma(I)$. Anisotropic displacement parameters were refined for all atoms. The relatively high residual electron-density of $29.05 \mathrm{e}^{-} / \AA^{3}$ corresponding to a peak in difference-Fourier located $0.1 \AA$ from Tl
Tab. 2 Chemical data (in wt. \%) for auerbakhite

\begin{tabular}{lrccl}
\hline Constituent & Mean & Range & Stand. Dev. & Reference material \\
\hline $\mathrm{Mn}$ & 7.34 & $7.28-7.47$ & 0.07 & $\mathrm{Mn}$ \\
$\mathrm{Tl}$ & 51.89 & $50.46-52.77$ & 0.77 & $\mathrm{Tl}(\mathrm{Br}, \mathrm{I})$ \\
$\mathrm{Pb}$ & 0.50 & $0.44-0.55$ & 0.04 & $\mathrm{PbSe}$ \\
$\mathrm{As}$ & 18.79 & $18.26-19.25$ & 0.38 & pararammelsbergite \\
$\mathrm{S}$ & 20.70 & $20.10-21.56$ & 0.51 & chalcopyrite \\
Total & 99.22 & & & \\
\hline
\end{tabular}
. 
Tab. 4 Atom positions and equivalent displacement parameters (in $\left.\AA^{2}\right)$ for auerbakhite

\begin{tabular}{lllll}
\hline Atom & \multicolumn{1}{c}{$\mathrm{x} / \mathrm{a}$} & \multicolumn{1}{c}{$\mathrm{y} / \mathrm{b}$} & \multicolumn{1}{c}{$z / c$} & $U_{\text {eq }}$ \\
\hline $\mathrm{Mn}(1)$ & 0.25 & $0.3564(15)$ & 0.25 & $0.032(4)$ \\
$\mathrm{Tl}(1)$ & 0 & $0.4126(4)$ & $0.17455(19)$ & $0.0398(12)$ \\
$\mathrm{Tl}(2)$ & $0.6431(2)$ & 0 & 0 & $0.0490(14)$ \\
$\mathrm{As}(1)$ & $0.1161(3)$ & $0.0348(8)$ & $0.1040(3)$ & $0.030(2)$ \\
$\mathrm{S}(1)$ & 0 & $0.845(2)$ & $0.1157(13)$ & $0.038(8)$ \\
$\mathrm{S}(2)$ & $0.1331(9)$ & $0.1097(18)$ & $0.2336(7)$ & $0.033(5)$ \\
$\mathrm{S}(3)$ & $0.2807(9)$ & $0.3304(19)$ & $0.0986(7)$ & $0.031(5)$ \\
\hline
\end{tabular}

The columns are framed by paired $\mathrm{AsS}_{3}$ pyramids with lone electron pairs oriented into interlayer space. Highly irregular $\mathrm{Tl}_{2} \mathrm{~S}_{6}$ coordination polyhedra are situated in interlayers and share ligands with the layers. Tl1 is a part of the complex (001) layer, interconnecting the Mn octahedral rods within this particular layer. atom is related to the poorly fitted absorption effects. The crystal size, the fact that the grain itself is embedded in a slightly larger matrix (soft-absorbing, but still) of calcite and probably also the quality of the crystal prevent us from fitting the absorption correction better. The crystal data and the experimental details are given in Tab. 3, atom coordinates, atomic displacement parameters and site occupancies in Tab. 4 and selected interatomic distances in Tab. 5. The CIF file is deposited at the Journal's webpage $w w w$.jgeosci.org.

Due to the lack of material for performing a conventional powder diffraction experiment, only the calculated powder pattern is given in Tab. 6 . The theoretical $d_{h k l}$ and relative intensities were calculated using the PowderCell program (Kraus and Nolze 1996).

\section{Description of the crystal structure}

The crystal structure of auerbakhite (Fig. 5) is identical to the structure of synthetic $\mathrm{Tl}_{2} \mathrm{MnAs}_{2} \mathrm{~S}_{5}$ prepared and investigated by Gostojić et al. (1982). The crystal structure consists of complex (001) layers based on a set of $\mathrm{MnS}_{4}$ columns, which are parallel to [010] and are composed of edge-sharing slightly irregular $\mathrm{MnS}_{6}$ octahedra (Tab. 5).

Tab. 5 Selected interatomic distances $(\AA)$ in auerbakhite

\begin{tabular}{|c|c|c|c|}
\hline $\mathrm{Mn} 1-\mathrm{S} 3$ & $2.570(12)$ & $\mathrm{As} 1-\mathrm{S3}^{\mathrm{iv}}$ & $2.230(16)$ \\
\hline $\mathrm{Mn} 1-\mathrm{S} 3^{\mathrm{iii}}$ & $2.570(12)$ & As1-S2 & $2.246(13)$ \\
\hline $\mathrm{Mn} 1-\mathrm{S} 2$ & $2.615(16)$ & As1-S1 xiv & $2.307(11)$ \\
\hline $\mathrm{Mn} 1-\mathrm{S} 2^{\mathrm{iii}}$ & $2.615(16)$ & & \\
\hline $\mathrm{Mn} 1-\mathrm{S} 2^{\mathrm{ii}}$ & $2.659(16)$ & & \\
\hline $\mathrm{Mn} 1-\mathrm{S} 2^{\mathrm{iv}}$ & $2.659(16)$ & & \\
\hline T11-S2 & $3.241(15)$ & $\mathrm{T} 12-\mathrm{S}^{\mathrm{vii}}$ & $2.972(14)$ \\
\hline $\mathrm{T} 11-\mathrm{S} 2^{\mathrm{vi}}$ & $2.964(14)$ & $\mathrm{T} 12-\mathrm{S} 3^{\text {viii }}$ & $2.972(14)$ \\
\hline $\mathrm{T} 11-\mathrm{S} 2^{\mathrm{ii}}$ & $2.964(14)$ & $\mathrm{T} 12-\mathrm{S} 3^{\mathrm{xi}}$ & $3.232(15)$ \\
\hline $\mathrm{T} 11-\mathrm{S} 2^{\mathrm{v}}$ & $3.241(15)$ & $\mathrm{T} 12-\mathrm{S} 3^{\mathrm{v}}$ & $3.232(15)$ \\
\hline $\mathrm{T} 11-\mathrm{S} 1$ & $3.453(17)$ & $\mathrm{T} 12-\mathrm{S} 1^{\mathrm{xii}}$ & $3.940(14)$ \\
\hline$\underline{\mathrm{T} 11-\mathrm{S}} 1^{\mathrm{ix}}$ & $3.523(17)$ & $\mathrm{T} 12-\mathrm{S} 1^{\mathrm{xv}}$ & $3.940(14)$ \\
\hline \multicolumn{4}{|c|}{$\begin{array}{l}\text { Symmetry codes: (i) } x, y-1 / 2,-z+1 / 2 \text {; (ii) } x, y+1 / 2,-z+1 / 2 \text {; (iii) }-x+1 / 2 \text {, } \\
y,-z+1 / 2 \text {; (iv) }-x+1 / 2, y+1 / 2, z \text {; (v) }-x, y, z \text {; (vi) }-x, y+1 / 2,-z+1 / 2 \text {; } \\
\text { (vii) } x-1 / 2, y+1 / 2, z \text {; (viii) }-x+1 / 2,-y+1 / 2,-z \text {; (ix) }-x, y-1 / 2,-z+1 / 2 \text {; } \\
\text { (x) }-x+1 / 2, y-1 / 2, z \text {; (xi) }-x+1,-y,-z \text {; (xii) } x+1 / 2, y-1 / 2, z \text {; (xiii) } x,-y \text {, } \\
-z \text {; (xiv) } x, y-1, z \text {; (xv) } x+1 / 2,-y+1 / 2,-z \text {. }\end{array}$} \\
\hline
\end{tabular}

In auerbakhite, T11 and T12 are six-coordinated, although they are far from regular polyhedra. Both T11 and T12 have one-sided coordinations (Tab. 5), which suggest active lone electron pairs, all of which are directed into the interlayer space. Trigonal As pyramids are paired via a common S atom; along the [100] direction, a pyramidal pair matches two T12 polyhedra. The basal As-S distances of distorted $\mathrm{AsS}_{5}$ pyramids are $2.307 \AA$ opposed by 3.392

Tab. 6 Calculated powder X-ray diffraction data for auerbakhite (the $d_{h k l}$ spacings are given in $\AA$; only reflections with $I_{\text {rel.calc. }}>5 \%$ are given)

\begin{tabular}{|c|c|c|c|c|}
\hline$d_{\text {calc }}$ & $I_{\text {rel.calc. }}$ & $h$ & $k$ & $l$ \\
\hline 7.664 & 6 & 2 & 0 & 0 \\
\hline 6.337 & 22 & 1 & 1 & 1 \\
\hline 5.636 & 14 & 2 & 0 & 2 \\
\hline 5.289 & 11 & 1 & 1 & 2 \\
\hline 3.831 & 34 & 0 & 2 & 0 \\
\hline 3.733 & 11 & 0 & 2 & 1 \\
\hline 3.655 & 12 & 2 & 0 & 4 \\
\hline 3.555 & 10 & 1 & 1 & 4 \\
\hline 3.480 & 33 & 4 & 0 & 2 \\
\hline 3.480 & 10 & 0 & 2 & 2 \\
\hline 3.374 & 100 & 3 & 1 & 3 \\
\hline 3.356 & 6 & 2 & 2 & 1 \\
\hline 3.168 & 5 & 2 & 2 & 2 \\
\hline 2.993 & 62 & 1 & 1 & 5 \\
\hline 2.818 & 7 & 4 & 0 & 4 \\
\hline 2.709 & 14 & 4 & 2 & 0 \\
\hline 2.620 & 5 & 3 & 1 & 5 \\
\hline 2.576 & 19 & 4 & 2 & 2 \\
\hline 2.532 & 18 & 5 & 1 & 3 \\
\hline 2.387 & 9 & 2 & 2 & 5 \\
\hline 2.245 & 6 & 1 & 1 & 7 \\
\hline 2.112 & 5 & 3 & 3 & 3 \\
\hline 2.090 & 8 & 7 & 1 & 1 \\
\hline 2.074 & 5 & 3 & 1 & 7 \\
\hline 2.002 & 5 & 3 & 4 & 4 \\
\hline 1.953 & 7 & 2 & 2 & 7 \\
\hline 1.916 & 10 & 8 & 0 & 0 \\
\hline 1.883 & 7 & 3 & 3 & 5 \\
\hline 1.879 & 8 & 6 & 0 & 6 \\
\hline 1.867 & 7 & 0 & 4 & 2 \\
\hline 1.827 & 5 & 4 & 0 & 8 \\
\hline 1.779 & 9 & 7 & 1 & 5 \\
\hline 1.713 & 6 & 4 & 4 & 0 \\
\hline 1.649 & 7 & 4 & 2 & 8 \\
\hline
\end{tabular}


Fig. 5 The crystal structure of auerbakhite projected along [010]; c-axis horizontal. Columns of Mn coordination octahedra (perpendicular to projection plane; red spheres) alternate with T11 polyhedra (large mauve spheres) in (001) layers, with $\mathrm{Tl}(2)$ coordination polyhedra in interlayers.

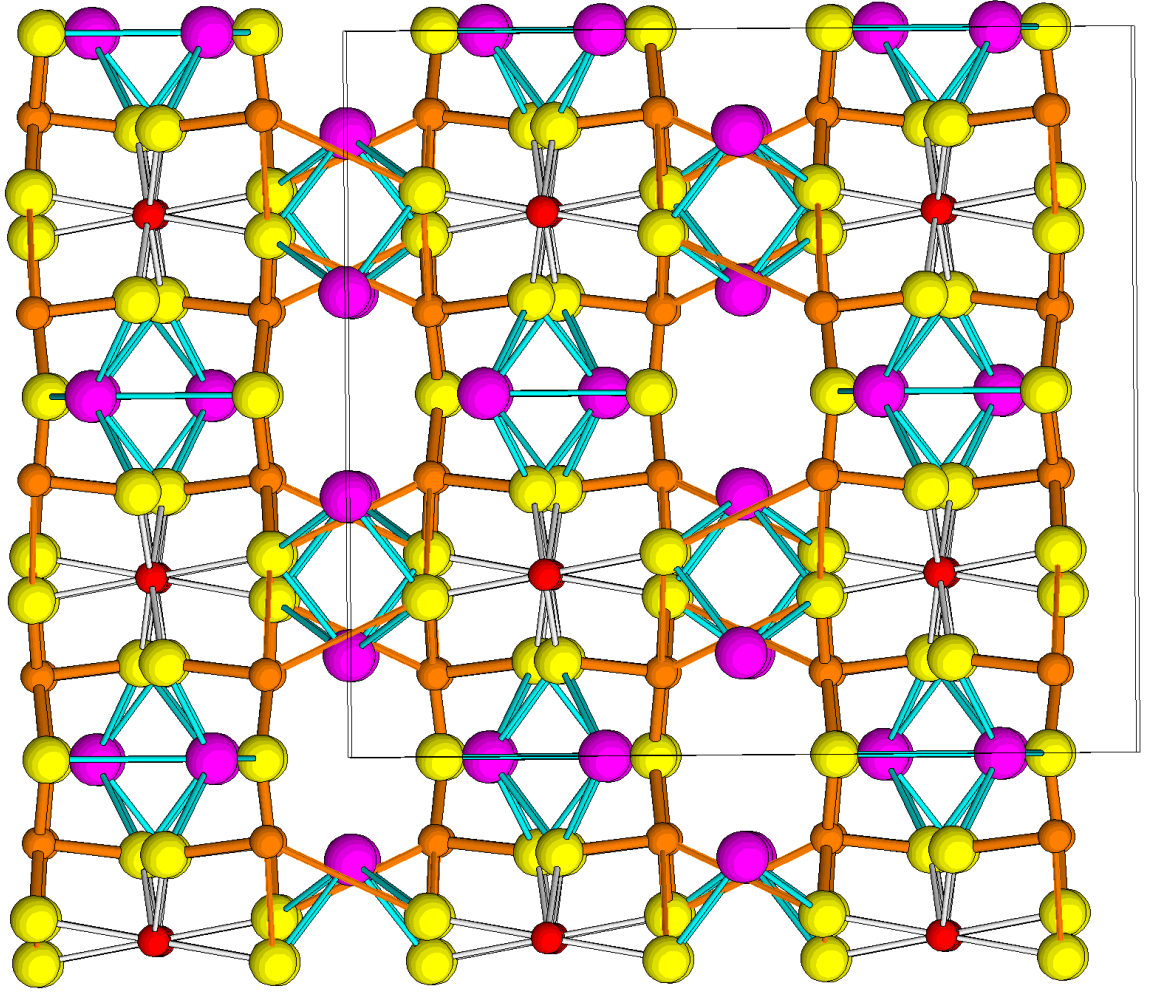

$\AA$, and $2.246 \AA$ opposed by $3.863 \AA$. The vertex distance of $2.228 \AA$ lacks a distant opposing distance within a $4 \AA$ range. The complete $\mathrm{AsS}_{5}$ pyramids are variously oriented and do not form a simple stacking sequence.

Like another Mn,Tl-sulfarsenite gladkovskyite $\mathrm{MnTlAs}_{3} \mathrm{~S}_{6}$ (Kasatkin et al. 2019), auerbakhite is characterized by a significant structural role of lone electron pairs of both arsenic and thallium and with a 'backbone' formed by relatively small coordination octahedra of divalent manganese. Columnar arrangements of Mn octahedra might play a similar role in the complex structure of tsygankoite (Kasatkin et al. 2018a).

\section{Remarks on the origin}

The complex mechanisms of hydrothermal-metasomatic processes with successive telescoping of ore mineral assemblages in combination with their superimposition on various volcanic-sedimentary and carbonate rocks became one of the causes of the distribution at Vorontsovskoe gold deposit of several sulfosalts with unique chemical compositions. Manganese does not belong to chalcophile elements, and sulfosalts with $\mathrm{Mn}$ are quite rare among minerals. Auerbakhite is one of those sulfosalts: it contains $\mathrm{Mn}, \mathrm{Tl}, \mathrm{As}$, and $\mathrm{S}$. The only other mineral with the same species-defining elements is gladkovskyite $\mathrm{MnTlAs}_{3} \mathrm{~S}_{6}$ (Kasatkin et al. 2019). However, it strongly differs from auerbakhite by stoichiometry and crystal structure. Both species were discovered in ore breccias, comprising one of the most interesting mineral assemblages of the deposit. We called it "gladkovskyite mineral assemblage" after the namesake sulfosalt described earlier and found in each of the studied specimens. A detailed description of this assemblage, its minerals and suggested sequence of mineral formation was given by Kasatkin et al. (2019, 2020b). Alternatively, this assemblage can be called "sulfarsenite": its main features are the arsenic character of ores represented by major orpiment and realgar, and complete absence of stibnite, usually relatively abundant at the deposit, along with general depletion in antimony. Accordingly, the list of minerals belonging to this assemblage includes no single sulfantimonite and, in general, their chemical composition is characterized by the absence of $\mathrm{Sb}$ or a strong dominance of As over Sb. Auerbakhite is one of the four sulfarsenites found at the Vorontsovskoe deposit only in this mineral assemblage, along with gladkovskyite, gillulyite and lorándite.

The development of ore breccias with accompanying metasomatic processes in marbled limestones composed of Mn-rich carbonates (calcite and dolomite) led to the formation of this unique mineral assemblage with $\mathrm{Mn}$ Tl-sulfarsenites. The high activity of sulfur and arsenic at the latest stages of the ore-forming process initiated the replacement of early high- and medium-temperature minerals of the base-metal ore association (galena, sphalerite, chalcopyrite, etc.) by rare sulfarsenites. Mechanisms of thallium concentration have not been determined unam- 
biguously, but we believe they were related to the interaction between post-magmatic hydrothermal solutions and carbonate rocks. As was suggested in our previous work (Kasatkin et al. 2019), the latter could perform a geochemical trap for ore-bearing solutions and became a place of concentration of thallium and formation of Tl-bearing sulfosalts. Low temperatures could promote the processes of separation of elements between different mineral phases.

To summarize, auerbakhite, similarly to gladkovskyite and other sulfarsenites of this mineral assemblage, was formed at the latest stage of low-temperature hydrothermal process due to the development of low-T metasomatic processes in sedimentary carbonate rocks rich in $\mathrm{Tl}$ and Mn connected with the saturation of the ore-forming environment by As with simultaneous very low activity of Sb.

Acknowledgments. Valuable comments by Jiř́ Sejkora and Martin Števko, as well as the handling editor František Laufek, helped in improving the manuscript. Fieldwork was carried out within the framework of the budget project AAAA-A18-118052590032-6 ("Paleogeodynamics and evolution of structure-chemical complexes during the formation of continental crust (by the example of the Ural-Mongolian Orogenic Belt and the West Siberian Platform")) of the state assignment of the Institute of Geology and Geochemistry UB RAS. The interpretation of the Raman spectrum was performed under the Russian state task, state registration No. AAAA-A19-119092390076-7.

Electronic supplementary material. Supplementary material consisting of crystal structure data (cif) are available online at the Journal website (http://dx.doi.org/10.3190/ jgeosci.321).

\section{References}

Anastassakis E, Perry CH (1976) Light scattering and IR measurements in $\mathrm{XS}_{2}$ pyrite-type compounds. J Chem Phys 64: 3604-3609

AuERBAKH AA (1869) The crystallographic study of celestine. Gornyi Zhurnal 7: 42-114 (in Russian)

FORNERIS R (1969) Infrared and Raman spectra of realgar and orpiment. Amer Miner 54: 1062-1074

Gostojić M, Edenharter A, Nowacki W, ENGel P (1982) The crystal structure of synthetic $\mathrm{Tl}_{2} \mathrm{MnAs}_{2} \mathrm{~S}_{5}$. Z Kristallogr 158: 43-51

Kasatkin AV, Makovicky E, PláśIL J, ŠKoda R, Agakhanov AA, Karpenko VY, Nestola F (2018a) Tsygankoite, $\mathrm{Mn}_{8} \mathrm{Tl}_{8} \mathrm{Hg}_{2}\left(\mathrm{Sb}_{21} \mathrm{~Pb}_{2} \mathrm{Tl}\right)_{\Sigma 24} \mathrm{~S}_{48}$, a New Sulfosalt from the Vorontsovskoe Gold Deposit, Northern Urals, Russia. Minerals 8: 218

Kasatkin AV, Nestola F, Agakhanov AA, Škoda R, Karpenko VY, Tsyganko MV, Plášil J (2018b) Vo- rontsovite, $\left(\mathrm{Hg}_{5} \mathrm{Cu}\right)_{\Sigma 6} \mathrm{TlAs}_{4} \mathrm{~S}_{12}$, and Ferrovorontsovite, $\left(\mathrm{Fe}_{5} \mathrm{Cu}\right)_{\Sigma 6} \mathrm{TlAs}_{4} \mathrm{~S}_{12}$ : The Tl- and Tl-Fe-Analogues of Galkhaite from the Vorontsovskoe Gold Deposit, Northern Urals, Russia. Minerals 8: 185

Kasatkin AV, Makovicky E, Plášil J, ŠKoda R, ChuKanov NV, Stepanov SY, Agakhanov AA, Nestola F (2019) Gladkovskyite, $\operatorname{MnTlAs}_{3} \mathrm{~S}_{6}$, a new thallium sulfosalt from the Vorontsovskoe gold deposit, Northern Urals, Russia. J Geosci 64: 207-218

Kasatkin AV, Makovicky E, PláśIL J, Š́oda R, Agakhanov AA, Stepanov SY, Palamarchuk RS (2020a) Luboržákite, $\mathrm{Mn}_{2} \mathrm{AsSbS}_{5}$, a new member of pavonite homologous series from Vorontsovskoe gold deposit, Northern Urals, Russia. Mineral Mag 84: 738-745

Kasatkin AV, Stepanov SYu, Tsyganko MV, ŠKoda R, Nestola F, Pláśill J, Makovicky E, Agakhanov AA, Palamarchuk RS (2020b) Mineralogy of the Vorontsovskoe gold deposit (Northern Urals). Part 1: History of study, mineral assemblages, list of minerals. Mineralogiya 6: 3-34 (in Russian)

Kasatkin AV, Makovicky E, PlášIl J, ŠKoda R, AgakhaNOV AA, Tsyganko MV (2020c) Pokhodyashinite, IMA 2019-130. CNMNC Newsletter No. 55; Mineralogical Magazine. Mineral Mag 84: 485-488

Kasatkin AV, Plášil J, Makovicky E, Chukanov NV, ŠKoda R, Agakhanov AA, Tsyganko MV (2021) Gungerite, $\mathrm{TlAs}_{5} \mathrm{Sb}_{4} \mathrm{~S}_{13}$, a new thallium sulfosalt with a complex structure containing covalent As-As bonds. Amer Miner, under review

Kraus W, Nolze G (1996): POWDER CELL - a program for the representation and manipulation of crystal structures and calculation of the resulting X-ray powder patterns. J Appl Cryst 29: 301-303

Merlet C (1994) An Accurate Computer Correction Program for Quantitative Electron Probe Microanalysis. Microchim Acta 114/115: 363-376

Minceva-Sukarova B, Jovanovski G, Makreski P, SoptraJANOV B, GRIFFITH W, WiLlis R, GRZETIC I (2003) Vibrational spectra of $\mathrm{M}^{\mathrm{I}} \mathrm{M}^{\mathrm{II}} \mathrm{S}_{2}$ type synthetic minerals $\left(\mathrm{M}^{\mathrm{I}}=\mathrm{Tl}\right.$ or $\mathrm{Ag}$ and $\mathrm{M}^{\mathrm{III}}=\mathrm{As}$ or $\mathrm{Sb}$ ). J Mol Struct 651-653: 181-189

Morimoto N (1954) The crystal structure of orpiment $\left(\mathrm{As}_{2} \mathrm{~S}_{3}\right)$ refined. Mineral J 1: 160-169

MulLEN DJE, NOWACKI W (1972) Refinement of the crystal structures of realgar, AsS and orpiment, $\mathrm{As}_{2} \mathrm{~S}_{3}$. Z Kristallogr 136: 48-65

Petř́ičé V, Dušek M, Palatinus L (2014) Crystallographic computing system Jana2006: general features. Z Kristallogr 229: 345-352

RigAKu (2019) CrysAlis CCD and CrysAlis RED. RigakuOxford Diffraction Ltd, Yarnton, Oxfordshire, UK

Vikentyev IV, Tyukova EE, Murzin VV, Vikentyeva OV, PAVLov LG (2016) The Vorontsovsk gold deposit. Geology, gold modes, genesis. Yekaterinburg, Fort Dialog-Iset: 1-204 (in Russian) 